\title{
Agricultural Injuries: A Global Rural Health Problem
}

\section{Antonios G Angoules*}

Department of Essential Medical Subjects, Faculty of Healthcare Professions, Technological Educational Institute, Athens, Greece

Agriculture is a major traditional occupation which is spread worldwide and is also strongly related to a number of health problems. A considerable amount of medical cases, especially work-related injuries have their origin in this activity. As of 1985, agriculture was ranked as the fourth most injury-prone industry in the United States, with only mining, transportation, communication and construction having higher morbidity rates [1].

Farming is a physically and emotionally demanding industry and work related health problems are common among the agricultural workers. Causing a substantial physical damage, they are also accompanied by a serious direct and indirect economic burden. It is estimated in the United States in 1992 to reach an amount of $\$ 4.57$ billion (range $\$ 3.14$ billion to $\$ 13.99$ billion), for all age groups combined [2]. In the UK a recent survey focusing on male, selfemployed agricultural workers aged $14-64$ year old, reported at least one occupational accident, leading to absence from work for 3 or more days [3].

Farmyard injuries affect all age groups of farmers. Especially over 55 years greater risk of serious injury than their younger counterparts was found [4-6]. Farmyard injuries in young adults and the elderly usually result from machinery accidents, whereas children tend to be injured by animals, runovers and motor vehicle collisions [7].

Risk factors include intrinsic (behavioral) and environmental parameters. Exposure to environmental hazards encompasses many dangers i.e. unguarded machinery, animals, agricultural chemicals, dust and airborne toxins, compressed air and temperature extremes [6].

Voaklander et al. [4] in a recent review in 2009, postulated that most commonly reported human factors for their significant contribution to agricultural injury include previous injury, hearing problems, depression, arthritis, and sleep deprivation.

The combination of factors such as the farm worker's behaviour, the machinery, and the environment all result in a great number of farm accidents [8].

A great number of agricultural work-related accidents ranging from trivial or non fatal to even life threatening injuries have been encountered during this dangerous occupation. Such incidents also may result in permanent disability.

Motor vehicle and machinery accidents, as well as falls and electrocution may result in lethal injuries $[9,10]$ which are found to be most common in July, August and September, the main months for harvesting [10]. On the other hand most of the non-fatal injuries in the UK during 1996-2003, the highest rates of agricultural accidents resulted from handling, lifting or carrying (4.9/1000 person-years), falls from height (4.6/1000 person-years) and injury by animals (3.4/ 1000 person-years) [3].

Non fatal pathologies constitute a great variety. Hand injuries, fractures, dislocations, sprains, contusions and intra-cranial, chest and other internal organ lesions as well as animal bites and burns have been encountered. The severity of these injuries varies from simple softtissue lacerations to severe limp amputations [7].
Other farming work-related pathologies include pesticide poisoning, peasant syndrome and respiratory, musculoskeletal, infectious and skin diseases $[11,12]$.

There are several issues regarding farmyard injuries which should be taken into consideration when faced. Farmers often work in isolation far away from organized health units. Hence the immediate transport of the wounded person to nearest medical centre is essential and potentially lifesaving. The optimal first aid in the place of accident should be provided by trained health professionals to minimize the undesirable consequences of injuries and to prevent further injury to the person.

Agricultural accidents, even superficial skin lacerations, are a different category of injuries as they take place in a highly bacterial contaminated environment [13]. The initial management of these injuries should be based on a thorough examination and detection of all factors that compromise wound healing and place the patient at risk of infection. These are diabetes mellitus and the use of immunosuppressive medication [14]. Other special characteristics such as jagged wound edges, stellate shape, injury deeper than the subcutaneous tissue, presence of foreign bodies and lacerations other than those on the head and neck should be thoroughly evaluated as contributing to an increased risk of infection [15].

Immunisation status should be documented and with no history of tetanus toxoid in the previous 5 years, tetanus immunoglobulin is indicated $[14,16]$.

Hand injuries during farming activities are common. The daily contact with increasingly powerful mechanisation exposes farm workers and their family members to high risk of upper extremity injuries. These are high energy injuries associated with a high microbiological load. It should be taken into consideration that repetitive debridements, prolonged hospitalization and delayed return to work has been reported for these lesions [17]. In the event of an amputated part immediate care is vital, investigating the possibility of surgical reattachment.

Open fractures are complex injuries that often result from high energy farming trauma and involve both the bone and surrounding soft tissues. These injuries are associated with an increased risk of infection and healing complications [18]. Haemorrhage control, check of the neurovascular status of the limb, exclusion of compartment syndrome, removal of easily accessible foreign bodies, realignment and splinting of the fracture represent the therapeutic priorities [7].

*Corresponding author: Antonios G Angoules, Department of Essential Medical Subjects, Faculty of Healthcare Professions, Technological Educational Institute Athens, Greece, E-mail: antoniosangoules@yahoo.com

Received June 10, 2012; Accepted June 11, 2012; Published June 13, 2012

Citation: Angoules AG (2012) Agricultural Injuries: A Global Rural Health Problem. J Trauma Treat 1:e106. doi:10.4172/2167-1222.1000e106

Copyright: (C) 2012 Angoules AG. This is an open-access article distributed unde the terms of the Creative Commons Attribution License, which permits unrestricted use, distribution, and reproduction in any medium, provided the original author and source are credited. 
Farm injuries create particular concerns as they are, a priori, considered contaminated with anaerobic organisms and there is always the risk of clostridial myonecrosis (gas gangrene) [16].

Tetanus prophylaxis should follow the Department of Health guidelines [19]. Irrigation and thorough surgical debridement in combination with intra antibiotic administration is of paramount importance [16,18,10-22].

Many agricultural workers are exposed to a daily contact with animals and bites are common injuries. Oral flora, thought different among animal species, is enriched with a broad range of pathogenic microorganisms [23]. The use of prophylactic antibiotics must be judicious. They are solely recommended for high-risk bite wounds for fear of the risk of unnecessary adverse events and the development of resistance to medication [24,25].

All wounds require copious irrigation and debridement of any devitalized tissue. As far as wound closure is concerned, relatively clean wounds can primary sutured. On the contrary if the wound is grossly contaminated, delayed primary closure is a preferred treatment option [26].

\section{Prevention}

Prevention of agricultural work-related injuries is crucial. The use of protective clothing, appropriate guards for dangerous parts, enforcement of the provision of safeguard in all farm equipment, better education and safety precaution have been proposed, accompanied by the appropriate design of rural trauma and emergency protocols $[5,7,9$ $11]$.

According to the Health and Safety Authority, farmers alone with their families and employees, are encouraged to make safety and health their priority [27]. Safety campaigns should be tailored especially to the increasingly older farmer [5].

Special precautions need to be taken with children. Staying clear of dangerous areas and a safe play area must be ensured. Furthermore, tractor wheels should be stored away from children's access. Fencing should be utilized to prevent children gaining access to hazardous areas, and safety from dangerous animals is necessary. The implementation of comprehensive farm safety programs aimed at children could be proven to be a promising element of safety programs $[9,27]$.

\section{References}

1. Bell CA, Stout NA, Bender TR, Conroy CS, Crouse WE, et al. (1990) Fata occupational injuries in the United States, 1980 through 1985. JAMA 263: 3047-3050.

2. Leigh JP, McCurdy SA, Schenker MB (2001) Costs of occupational injuries in agriculture. Public Health Rep 116: 235-248.

3. Solomon C, Poole J, Palmer KT, Coggon D (2007) Non-fatal occupational injuries in British agriculture. Occup Environ Med 64: 150-154.

4. Voaklander DC, Umbarger-Mackey ML, Wilson ML (2009) Health, medication use, and agricultural injury: A review. Am J Ind Med 52: 876-889.

5. Byrne FJ, Waters PS, Waters SM, Hynes S, Ní Thuairisg CP, et al. (2011) Demographics, nature and treatment of orthopaedic trauma injuries occurring in an agricultural context in the West of Ireland. Ir J Med Sci 180: 185-189.

6. Pickett W, Hartling L, Dimich-Ward H, Guernsey JR, Hagel L, et al. (2001) Surveillance of hospitalized farm injuries in Canada. Inj Prev 7: 123-128.

7. Angoules AG, Lindner T, Vrentzos G, Papakostidis C, Giannoudis PV (2007) Prevalence and current concepts of management of farmyard injuries. Injury 5: S27-S34.

8. Wright KA (1993) Management of agricultural injuries and illness. Nurs Clin North Am 28: 253-266.
9. Pickett W, Hartling L, Brison RJ, Guernsey JR (1999) Fatal work-related farm injuries in Canada, 1991-1995. Canadian Agricultural Injury Surveillance Program. CMAJ 160: 1843-1848.

10. Solomon C (2002) Accidental injuries in agriculture in the UK. Occup Med (Lond) 52: 461-466.

11. Lee SJ, Kim I, Ryou H, Lee KS, Kwon YJ (2012) Work-related injuries and fatalities among farmers in South Korea. Am J Ind Med 55: 76-83.

12. Lee SJ, Kim I, Ryou H, Lee KS, Kwon YJ (2012) Work-related injuries and fatalities among farmers in South Korea. Am J Ind Med 55: 76-83.

13. Rodeheaver G, Pettry D, Turnbull V, Edgerton MT, Edlich RF (1974) Identification of the wound infection-potentiating factors in soil. Am J Surg 128: 8-14.

14. DeBoard RH, Rondeau DF, Kang CS, Sabbaj A, McManus JG (2007) Principles of basic wound evaluation and management in the emergency department Emerg Med Clin North Am 25: 23-39.

15. Hollander JE, Singer AJ, Valentine SM, Shofer FS (2001) Risk factors for infection in patients with traumatic lacerations. Acad Emerg Med 8: 716-720.

16. Gustilo RB, Merkow RL, Templeman D (1990) The management of open fractures. J Bone Joint Surg Am 72: 299-304.

17. Cem Copuroglu, Nurettin Heybeli, Mert Ozcan, Baris Yilmaz, Mert Ciftdemir, et al. (2012) Major Extremity Injuries Associated with Farmyard Accidents. The Scientific World Journal.

18. Zalavras CG, Marcus RE, Levin LS, Patzakis MJ (2008) Management of open fractures and subsequent complications. Instr Course Lect 57: 51-63.

19. Forward D, Moran CG (2002) Diagnosis and immediate care of open fractures Hosp Med 63: 298-299.

20. Crowley DJ, Kanakaris NK, Giannoudis PV (2007) Irrigation of the wounds in open fractures. J Bone Joint Surg Br 89: 580-585.

21. Patzakis MJ (1982) Management of open fractures and complications. Instr Course Lect 31: 62-64.

22. Zalavras CG, Patzakis MJ (2003) Open fractures: evaluation and management J Am Acad Orthop Surg 11: 212-219.

23. Dendle C, Looke D (2008) Review article: Animal bites: an update fo management with a focus on infections. Emerg Med Australas 20: 458-467.

24. Nakamura Y, Daya M (2007) Use of appropriate antimicrobials in wound management. Emerg Med Clin North Am 25: 159-176.

25. Norton C (2008) Animal and human bites. Emerg Nurse 16: 26-29.

26. Okonkwo U, Changulani M, Moonot $P$ (2008) Animal bites: practical tips for effective management. J Emerg Nurs 34: 225-226.

27. (2006) Preventing Injury and Occupational III Health in Agriculture. Health and Safety Authority. 